The last published report of the work of his observatory was for the year 1950 . On closing it down finally, he presented some of his instruments to the Royal Greenwich Observatory at Herstmonceux.

Evershed married in 1906 Miss Mary Acworth, and she collaborated actively with him in his researches until her death in 1949 . He was married a second time in 1950, to Miss Margaret Randall, who survives him. F. J. M. STRATTON

\section{Dr. A. J. Carlson}

When he died on September 2, Dr. Anton Julius Carlson bore the illustrious title of "Frank P. Hixon distinguished service professor emeritus of physiology, University of Chicago".

Carlson was born in Sweden in 1875 and went to the United States in 1891. He graduated A.B. at Augustana College, Rock Island, Illinois, in 1898, A.M. the following year, and Ph.D. in physiology at Stanford University in 1903. After spending one year as a research associate at the Carnegie Institution, he joined the Department of Physiology of the University of Chicago in 1904 and remained there until he retired in 1940 from the positions of professor and chairman of the Department. As professor emeritus he continued actively at work, and himself told a Committee of the House of Representatives in 1950 that "for the last ten years I have been emeritus or demeritus, whatever you call it; however, the only thing I retired from ten years ago was my salary". In the U.S. Army during 1917-19 he was a lieutenant-colonel in the Sanitary Corps, and while serving in Sweden was given the honorary degree of M.D. by Lund. He held honorary degrees from seven universities.
Carlson's early work was on the rate of conduction of impulses in nerves and, after some excursions into the comparative physiology of the circulation, he did his main work upon the physiology of the alimentary tract and of the visceral sensory nervous system. Apart from some two hundred papers, he wrote two books : "Control of Hunger in Health and Disease" and "The Machinery of the Body".

Carlson was honoured by many institutions. He was elected to the U.S. National Academy of Sciences in 1918, to the American Physiological Society in 1904 (being secretary during 1910-14 and president 1923-25), and to a variety of others in the United States and abroad. He had also served as president of the American Association for the Advancement of Science, the American Biological Society, the Federation of American Societies for Experimental Biology, the Institute of Medicine, the American Association of University Professors, and the National Society for Medical Research. In 1935 he lectured in China under the auspices of the Rockefeller Foundation, and he was a frequent traveller, attending seven international physiological congresses between 1909 and 1950, and the international gerontological congress in London last year.

Carlson was a great teacher, and himself said that he had taught between 8,000 and 10,000 medical students, and 75,000-100,000 other students. He was forthright, very outspoken and a keen controversialist. His work as a consultant on Government organizations (such as the Food and Drug Administration and the Office of Scientific Research and Development) often enlivened meetings; but surprising though his statements sometimes appeared, they were always backed by experimental facts, often elicited in his own laboratory.
H. M. Sinclair

\section{NEWS}

\section{Hungary: American Scientists' Resolutions}

THE U.S. National Academy of Sciences at its autumn meeting in Washington adopted the following resolution respecting recent events in Hungary: "Those members of the National Academy of Sciences of the United States of America present at a meeting in Washington on November 10, 1956, unite in expressing their profound admiration and sympathy to fellow scientists in Hungary and to all the men and women of that nation who have demonstrated their love of liberty with sacrificial devotion during the tragic events of the past few weeks. American scientists look forward with hope to a time when their Hungarian colleagues, freed from external oppression, will be able to join fully in the international exchange of information, discussion and encouragement which is essential to the progress of science". Dr. Detlev W. Bronk, president of the Academy, expressed his satisfaction that the Academy's resolution could be associated with a similar statement adopted by the American Philosophical Society. "It is appropriate," he said, "that the Academy should join with the American Philosophical Society, the oldest of the great scholarly societies of the United States, in a matter so closely related to the unconquerable yearning of mankind freely and courageously to advance its highest human and cultural ideals. The statements of the Academy and of the Society recognize with humility and deep gratitude the desperate and courageous struggle of

\section{nd VIEWS}

Hungarians for those principles which are precious to all who value the right to seek truth and to teach it freely."

\section{Institute of Metals : Awards}

THE Institute of Metals have made the following awards: Institute of Metals (Platinum) Medal for 1957 : Dr. Maurice Cook, joint managing director, Imperial Chemical Industries, Ltd., Metals Division, in recognition of his outstanding contribution to the science of metallurgy, to the non-ferrous metals industry and to the welfare of the metallurgical profession; Rosenhain Medal for 1957: Dr. H. K. Hardy, research manager, United Kingdom Atomic Energy Authority, Industrial Group, in recognition of his outstanding contributions to knowledgo in the field of physical metallurgy.

\section{University of Leeds Appeal}

IMMEDIATELY before the War the number of fulltime students at the University of Leeds was about 1,750. The number has now increased to 3,700 and, among these, the number reading science or technology has grown from 560 to 1,700 . In five or six years time it is expected that there will be 5,300 students in all, of whom 3,000 will be reading science or technology. During the past sixteen years the research work of the University has developed at a rapid rate and will develop even more quickly in the next five or six years. To meet these demands, the 